\title{
Globalization in Trade or Trade Restrictions? A Study of Post-War and Recent Trends
}

\author{
Mehdi Monadjemi ${ }^{1}$, John Lodewijks ${ }^{1}$ \\ ${ }^{1}$ Visiting fellow and adjunct professor at the School of Economics, University of New South Wales Sydney 2052 \\ Australia and SP Jain Global, Australia \\ Correspondence: Mehdi Monadjemi, visiting fellow at the School of Economics, University of New South Wales \\ Sydney 2052 Australia.
}

Received: January 20, 2020

Accepted: February 6, $2020 \quad$ Available online: February 10, 2020

doi:10.11114/aef.v7i2.4712

URL: https://doi.org/10.11114/aef.v7i2.4712

\begin{abstract}
Despite all of the advantages of free trade and WTO effort to discourage trade restrictions, in July 2018, the President of the United States decided that he is going to impose tariffs on certain goods imported from China. The Chinese government retaliated by levying tariffs on goods and services imported from the United States. This trade war is opposite of the trend in

international trade during the Post-war period. While the trade deficit figures have improved this has occurred at considerable cost. Tariffs on imported goods are a tax on domestic consumers.
\end{abstract}

Keywords: tariffs, imports, balance of trade, World Trade Organization, trade war

\section{Introduction}

After four decades of movements towards globalization in trade and finance, in 2018 President Trump announced that he wanted to reverse the trend by introducing tariffs on imported goods from China. Chinese authorities predictably retaliated. The trade war intensified. This has alarmed US and global financial markets and encouraged the global flight to cash and gold.

The East Asia Forum Digest of 26 August 2019 wrote the following:

There has been an assault on the multilateral economic institutions and rules that have provided the foundations for global growth. The strength of the North American economy, including its technological vibrancy, the growth of Europe and the lifting of hundreds of millions of people out of poverty, most notably in Asia, have all depended in crucial ways on that system - and still they do. The free flow of trade, investment, and ideas has supported the emergence of a growing middle class around the world. The return to unilateralism and disregard for established processes affect investor confidence and drag down trade and growth. The IMF and other international agencies are now revising growth forecasts downwards. Last year, the volatility of the global economy and many currencies, decreased international capital flows and increased uncertainties in global trade. This year, the global economic situation continues to deteriorate, and the uncertainties are growing. These uncertainties create downside risks to the global economy and increase financial market volatility. Economic activity is weakening. Trade and manufacturing activities are slowing. Growth remains low and the risks are all downside, significantly because of trade uncertainty. The hit to global trade continues to dampen investment and business sentiment and lower productivity.

This article examines the post-war move to freer international trade and the recent retrogressive steps back to protectionism.

\section{The Post-War Liberalization of Trade}

Globalization has many dimensions; cultural integration, immigration, scientific and technology integration and economic globalization. We concentrate on the economic globalization of international trade.Trade globalization is the process of enhancing trade integration between nations, leading to the gradual development of a single world market for trade of goods and services. 
In 1960, less than one-sixth of the countries in the world had open trade policies. Most countries had various types of trade restrictions such as high tariff rates (taxes on imports) and extensive non-nontariff barriers (such as quotas which that restricted the physical quantity of specific imports allowed into a country). In addition, the official exchange rate often exceeded the black black-market exchange rate, and governments exercised monopoly controls on exports and other trade-related matters. Yet by 2000 three-quarters of the countries in the world had removed many of these impediments and were now open to international trade. This is a remarkable transformation and highlights the importance of trade liberalization in the global economy.

What precipitated the extensive trade liberalization that occurred? Much of the credit is usually given to the sixty years of multilateral trade negotiations that has resulted in ever-lower trade barriers under the auspices of the General Agreement on Tariffs and Trade (GATT). Since GATT's inception in 1947, manufacturing tariffs in industrialized countries have fallen from 40 percent to 4 percent, and world trade has increased 18-eighteenfold.

Initial GATT membership of 23 countries expanded to 148 countries and the trade rounds became the international forum in which member governments agreed on rules for the conduct of international trade. The multilateral trade agreements involved non-non-discriminatory tariff reductions so that all countries benefited-the "most favoured nation" clause - and the tariff cuts were "binding" and could not be restored at a later date.

Countries would not have agreed to lower levels of import protection unless there were good arguments in their favour. Trade liberalization allows countries to specialize production and export in their areas of relative strength and to import products that other countries can make at lower cost. It enables access to a wider range of products, and access to foreign products helps diffuse innovations and new technologies. Openness to trade provides additional competition that can spur local firms to greater efficiency and keeps domestic prices low.

In the context of developing countries, a series of country studies sponsored by the World Bank, the Organization for Economic Cooperation and Development (OECD), and the National Bureau of Economic Research demonstrated that trade barriers imposed significant costs, whereas while trade openness appeared to be associated with improved economic performance. For these countries, import substitution using high effective rates of protection had been the dominant vehicle by which industrialization has proceeded. Initially, local suppliers would have to be nurtured and protected from the competitive pressures applied by long established foreign producers. Over time, domestic inefficiencies would decline as these "infants" learned from experience and were able to reduce costs of production. The end result would be a far more diversified and self-reliant industrial structure less dependent on the vagaries of international commodity prices. In the 1970s increasing disenchantment with this strategy emerged, and an alternative approach, identified as outward- (or export-) oriented and associated with East Asian development, became more popular and trade barriers fell (Sebastian Edwards, 1993).

While trade barriers in manufacturing have fallen extensively, the trade liberalization agenda has now expanded its scope and consequently run into considerable difficulties. In 1995 GATT's successor, the World Trade Organization (WTO), became operational. Whereas GATT focused on trade in goods, the WTO concentrates on trade in services, intellectual property, and agricultural subsidies. According to the OECD, rich countries spend $\$ 280$ billion a year on agricultural producer support; and agricultural price support amounts to 20 percent in the United States, 50 percent in Europe, and 80 percent in Japan. These agricultural subsidies are trade-distorting, and encourage those encouraging supported farmers to produce more, and this in turn lowers world prices and hurts farmers in poor countries that have a comparative advantage in the production of these subsidized commodities. Poor countries want agricultural liberalization in rich countries, yet there has been little progress has occurred in persuading richer countries to dispense with these subsidies.

Trade in services, especially related to issues of labour mobility across national boundaries, and "TRIPs" - trade-related aspects of intellectual property rights — which are of special interest to the pharmaceutical and software industries, are equally contentious issues. The latter is related to the manufacture of generic drugs and their sales to poor countries. Claims for "fair trade" rather than "free trade" cloud trade negotiations even further, because. The issue here is that non-government organizations have been advocating "social clauses" in trade liberalization agreements relating to child labour, human rights, the environment, wages, and conditions. The position taken is that trade sanctions should be imposed against countries that do not meet international standards in these areas.

Given these stumbling blocks and complications, it is not surprising that there has been a move away from multilateral forums to negotiated bilateral or regional trade agreements outside the WTO framework. More than 300 such preferential trade agreements now exist. Whether these agreements assist global trade liberalization or hinder the process is not clear.

Trade liberalization itself is only part of a broader globalization movement and it needs to be carefully sequenced with other policy reforms. In general, trade liberalization should precede financial liberalization, domestic financial liberalization should precede external financial liberalization, and direct investment liberalization should precede portfolio and bank loan liberalization (capital account liberalization). Free inflows of foreign financial capital should only 
be allowed at the tail end of a liberalization program, and controls on suddenly increased inflows of short-term capital may be warranted. The purpose of these controls is to quarantine economies from excessive "hot" money inflows and outflows that disrupt economic stability and lead to exchange rate misalignments.

Overall, the welfare effects of trade liberalizations fall within the realm of second-best economics. There is still dispute about the direction of causation in the association between openness to trade and East Asia's rapid growth. What role have trade liberalisation liberalization packages played in the performance of outward-oriented economies? A number of these countries, such as Japan, Korea, Singapore, and Taiwan, have promoted exports, but in an environment where imports had not been fully liberalised. The success of the East Asian countries with export-led growth suggests that some selectively determined degree of government intervention played a key role. Imports and lower tariffs may stimulate productivity but import competition may have little impact on productivity growth if the domestic producers are technologically back-ward. The beneficial effects only occurred if Benefits accrue only to domestic producers that are roughly comparable to their foreign counterparts. This, then, suggests a role for trade trade-adjustment packages and safety nets for those disadvantaged by trade liberalization.

\section{The State of World Trade Until the Recent Upheavals}

In his book, The World Economy: A Millennial Perspective, Angus Maddison (2001) has presented a comprehensive quantitative analysis of the economic performance of nations since the year 1000. He identifies the period 1950 to 1973 as a 'golden age' of unparalleled prosperity where the world economy grew much faster than it had ever done before and this dynamism affected all regions. Average incomes rose rapidly. The business cycle, with its erratic swings of high unemployment and then high inflation, virtually disappeared. Trade liberalization played a part in this prosperity.

The volume of world trade increased 27-fold from \$296 billion in 1950 to $\$ 8$ trillion in 2005" (WTO, 2007). In Table1 total merchandise exports for the world and the selected top exporting countries and regions are presented. In years 2015 and 2016, world exports have declined. This is a result of the struggling economies of Europe and downturn in Chinese's economy. The year 2015 was the worst year for the world exports. However, in 2017, the world exports as well as exports of all the top exporters improved.

In recent years, China has experienced an economic slowdown along with the rest of the world, and many worries that because of its position in the world trade market, any downturn will have a world-wide impact. In the years leading up to the global recession, China was growing at an unprecedented pace. However, the Beijing government recently predicted a rate of seven percent growth, for the next year, a slowdown for the previously hot Chinese's

economy. China maintains the world's largest reserves of US treasuries, which makes it vital in determining the amount of trade that occurs in the world market.

Table 1. Total Merchandise Exports Billions of US dollars

\begin{tabular}{|l|l|l|l|l|l|l|}
\hline Year & 2012 & 2013 & 2014 & 2015 & 2016 & 2017 \\
\hline World & 18629 & 19072 & 19106 & 16636 & 16133 & 17846 \\
\hline China & 1372 & 1443 & 1438 & 1209 & 1195 & 1413 \\
\hline Europe* & 6129 & 6338 & 6809 & 5887 & 5850 & 6406 \\
\hline Japan & 819 & 808 & 761 & 603 & 566 & 633 \\
\hline US & 2252 & 2268 & 2349 & 2197 & 2132 & 2302 \\
\hline 4 Asian & 1489 & 1549 & 1541 & 1321 & 1244 & 1373 \\
\hline
\end{tabular}

This table is based on data collected from the WTO site. * the 2012 and 2013 data on Europe includes 15 countries with highest merchandize exports, collected from: World Atlas - Statistics by Country https://en.actualitix.com/country/eurp/europe-merchandise-exports.php

Further insight into the world exports is presented in Figure 1 where quarterly data on total merchandise exports of a group of top countries for the past 25 years is plotted. All the five countries' exports rose sharply in the early 2000s, roughly when rapid removal of the trade barriers started. The sharpest rise in exports was experienced by China. All the five countries' exports fell during the Great Recession in 2007 - 2008. Chinese, US and Germany's exports recovered after the GR, but Japanese and Six Asians remained relatively stable from 2009 to 2017. 


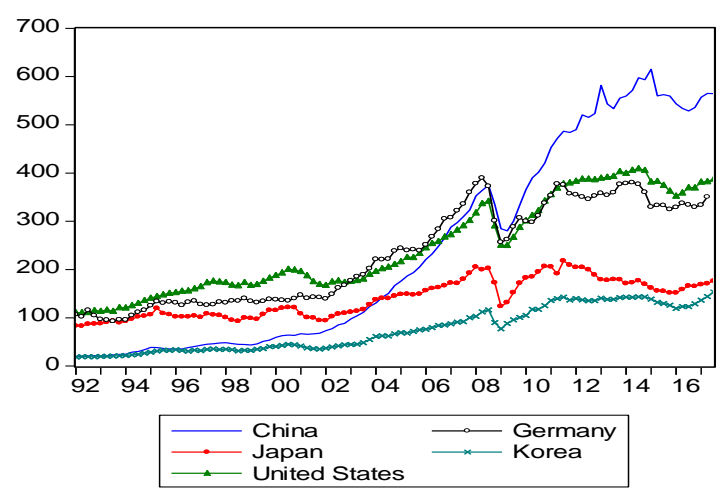

Figure 1. Selected Countries’ Total Merchandise Exports 1992 - 2017

Figure 1 was collected from Monadjemi and Lodewijks (2019)

As a result of increased international trade, consumers around the world enjoy a larger choice of goods and services than they would if their choice restricted had to domestically made products.

Higher international trade has contributed to the economic growth across the world raising incomes, higher employment, falling prices, and increasing workers' purchasing power. The WTO reports that percentage of people in the world living less than 1.90 US\$ has decreased from 42.1 percent in 1981, to 9.9 percent in 2015.

However, since the global economy is so inter-related through trade and capital flows, when large economies suffer instabilities, the effects are transferred to the rest of the world. For example, when China's imports decrease, output and employment in China's exporting countries deteriorate. Globalization can improve and also deteriorate employment and economic activity. Furthermore, global interconnection of financial markets may cause financial crises to move from the original country to the rest of the world. The global financial crises of $2007-2008$ are an example of how sub-prime mortgage crises in the United States became global.

\section{The Recent Trade Wars}

Despite all of the advantages of free trade and WTO effort to discourage trade restrictions, the President of the United States decided that it is necessary to impose tariffs on certain goods imported from China. The Chinese government retaliated by levying tariffs on goods and services imported from the United States. These developments are opposite of the trend in international trade during the past three decades. China's exports, valued at 200 billion US dollars, are subject to a $10 \%$ tariff. US tariffs on an additional $\$ 16$ billion of Chinese exports are being introduced, adding the total under consideration to $\$ 250$ billion. President Donald Trump has threatened to move much further - possibly targeting as high as $\$ 550$ billion.

The following data from 2018, reported by CNN world news provides the apparent justification for the introduction of tariffs on China's goods.

Table 2. US Trade Balance in Goods 2018 in billions of US dollars

\begin{tabular}{|l|l|l|}
\hline US imports goods from China & Chinese imports goods from US & US trade deficit in goods with China \\
\hline 505 & 130 & 376 \\
\hline
\end{tabular}

US tariffs policy is designed to encourage consumers to buy domestically produced goods by making imported goods more expensive. So far, the US has imposed tariffs on more than $\$ 360 \mathrm{bn}$ worth of Chine's goods, and China has retaliated with tariffs on more than $\$ 110 \mathrm{bn}$ of US produced goods.

Washington has exercised three rounds of tariffs last year, and a fourth one in September. Beijing has retaliated with tariffs ranging from 5\% to $25 \%$ on US goods. Below in Table 3 is a list of tariffs imposed by the US and China since July 2018. See: A Quick Guide to US - China Trade War. https://www.bbc.com/news/business-45899310

Table 3. US and China Trade War in billions of US dollars

\begin{tabular}{|l|l|l|}
\hline & US Tariffs & China Tariffs \\
\hline July 2018 & $\underline{34 \text { billion }}$ & $\underline{34 \text { billion }}$ \\
\hline$\underline{\text { August 2018 }}$ & $\underline{16 \text { billion }}$ & $\underline{16 \text { billion }}$ \\
\hline September 2018 & $\underline{200 \text { billion at 10\% }}$ & $\underline{60 \text { billion at 10\% }}$ \\
\hline$\underline{\text { May 2019 }}$ & $\underline{200 \text { billion at 20\% }}$ & $\underline{-}$ \\
\hline June 2019 & $\underline{60 \text { billion at 5\% }}$ \\
\hline
\end{tabular}


As a consequence, The US trade deficit has fallen to its lowest level in three years. In November 2019 the trade shortfall fell by $8.2 \%$ to $\$ 43.1 \mathrm{bn}$, its lowest since October 2016 .

The key reasons for the fall are a declining deficit with China and the US becoming net exporter of oil.

However, while the trade deficit figures have improved this has come at considerable cost. Tariffs protect domestic producers and workers from foreign competition by increasing the prices of imported goods. In this respect, some argue that tariffs on imports are like a tax on domestic consumers. According to the Institute for International Economics, trade barriers cost American consumers $\$ 80$ billion a year, or more than $\$ 1,200$ per family, in increased prices for goods such as sugar (and foods made with it) and appliances made from steel. Another criticism of trade restriction is that they discourage the protected firms to become internationally competitive. Once the protected industries, they may have fewer incentives to improve their efficiency and management and remain dependent on government assistances for good.

To some extent the Trump Trade War is a reaction to the fact that global growth rates of income and output have been mediocre in recent times. Even the Chinese economy that grew on average at 10\% per annum from 1980-2010 is now approaching half that rate of growth. This is quite surprising given all the technology disruptive business activity involving artificial intelligence, blockchain, machine learning and robotics. The 4th industrial revolution does not appear to be visible in the growth and productivity statistics. What is visible is stagnant real wages for workers despite low unemployment. It is claimed that in America the real average wage has about the same purchasing power today as it did 40 years ago. The "blame" has been placed on cheap Chinese imports that have led to job losses and lower wages in the US. Hence the trade restrictions on Chinese goods. The resulting trade and currency wars among the two largest players in the global economy has clearly affected the real economy.

This leaves the global economy in a fragile state. Is there another crisis in the wings? Moreover, if there is, are we equipped to adequately respond? Interest rates are very low, even negative. Conventional monetary policy has reached its limits. As we write this, there are ominous signs of global recession in the context of a trade war between the US and China.

The lessons of history indicate that calm is needed and the steady removal of recently imposed trade barriers for the betterment of the global economy.

\section{References}

A Quick Guide to US - China Trade War. (2019). The East Asia Forum Digest of 26 August 2019. Retrived from https://www.bbc.com/news/business-45899310

Edwards, S. (1993). Openness, Trade Liberalization, and Growth in Developing Countries. Journal of Economic Literature, 31(3), 1358-1393.

Maddison, A. (2001). The World Economy: A Millennial Perspective, OECD, Paris. https://doi.org/10.1787/9789264189980-en

Monadjemi, M., \& Lodewijks, J. (2019). Financial Markets and the Global Economy. Bookboon, London, November.

Shambaugh, J., \& Nunn, R. (2017). Why Wages Aren’t Growing in America. Harvard Business Review, October 24.

\section{Copyrights}

Copyright for this article is retained by the author(s), with first publication rights granted to the journal.

This is an open-access article distributed under the terms and conditions of the Creative Commons Attribution license which permits unrestricted use, distribution, and reproduction in any medium, provided the original work is properly cited. 